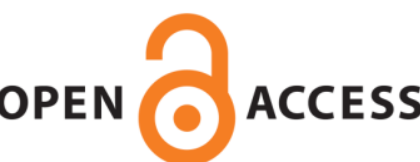

OPEN ACCESS

UWS Academic Portal

\title{
Corporate social responsibility as a legitimacy maintenance strategy in the professional accountancy firm
}

Duff, Angus

Published in:

The British Accounting Review

DOI:

10.1016/j.bar.2017.08.001

Published: 30/11/2017

Document Version

Peer reviewed version

Link to publication on the UWS Academic Portal

Citation for published version (APA):

Duff, A. (2017). Corporate social responsibility as a legitimacy maintenance strategy in the professional accountancy firm. The British Accounting Review, 49(6), 513-531. https://doi.org/10.1016/j.bar.2017.08.001

\section{General rights}

Copyright and moral rights for the publications made accessible in the UWS Academic Portal are retained by the authors and/or other copyright owners and it is a condition of accessing publications that users recognise and abide by the legal requirements associated with these rights.

Take down policy

If you believe that this document breaches copyright please contact pure@uws.ac.uk providing details, and we will remove access to the work immediately and investigate your claim. 


\title{
CORPORATE SOCIAL RESPONSIBILITY AS A LEGITIMACY MAINTENANCE STRATEGY IN THE PROFESSIONAL ACCOUNTANCY FIRM
}

\author{
Angus Duff, Ayr Campus, University of the West of Scotland, Ayr, KA8 0SX, UK.
}

\begin{abstract}
This paper investigates how accountancy firms use corporate social responsibility (CSR) as a device to maintain legitimacy with key constituents. It explores who these constituents (audiences) are for their CSR actions and the strategies they use to maintain legitimacy with these audiences. Interview-based evidence from 18 large accountancy firms in the United Kingdom (UK) identifies the main CSR constituents as: clients and potential clients of the firm; graduates as potential entrants to the industry; internal audiences represented by the firms' staff and partners; and other external audiences constructed as members of those local communities in which the firm operate. In the largest firms, maintaining pragmatic legitimacy with some client, graduate and internal audiences is frequently dependent on the development of moral legitimacy established with other external constituents (communities). Consequently, the typologies of legitimacy developed are largely pragmatic, the most ephemeral and most easily attained form, rather than something that is enduring, embedded and taken-for-granted.
\end{abstract}

Keywords: Accountancy industry; corporate social responsibility; legitimacy theory; legitimacy maintenance strategy. 


\section{Introduction}

PwC is founded on a culture of partnership with a strong commercial focus. This is reflected in our vision: "One firm - a powerhouse of a commercial enterprise that does the right thing for our clients, our people and our communities."

(PwC, 2011)

This paper aims to advance our theoretical and empirical understanding of how practitioners in accountancy firms use corporate social responsibility (CSR) activities to support the legitimacy maintenance strategies (LMS) of their organisations. This aim is achieved by undertaking semi-structured interviews with key organisational actors responsible for CSR within each of the Big Four and a further 14 mid-tier accountancy practices in the UK. Twenty-three interviews in total were undertaken with these 18 firms. The theoretical lens used to evaluate firms' actions is Suchman's (1995) tri-level theory of legitimacy and conceptualisation of the process of the maintenance of legitimacy.

CSR scholars have suggested that business enterprises face increasing demands from internal and external sources to demonstrate varying degrees of social responsibility (Aguilera Rupp, Williams, \& Ganapathi, 2007; Basu \& Palazzo, 2008; Carroll \& Shabana, 2010; Castello \& Lozano, 2009, 2011; den Hond \& de Bakker, 2007; Matten \& Moon, 2007). Accountancy firms provide a novel and underexplored site for CSR research and complements Duff's (2016) recent analysis of UK accountancy firm's corporate social disclosures. In particular, Author (2016 p.75) identifies that 'the reporting of CSR activity is a precursor of signalling legitimacy, status and reputation (prestige) within the accountancy industry' and that corporate social disclosure 'assists the process of attracting large numbers of high quality graduates'. It is argued that the CSR activities undertaken by professional accountancy firms are motivated by a need to maintain legitimacy in particular with three audiences: clients; existing employees/partners; and 'talent', in the form of graduates and school-leavers seeking professional employment and training opportunities. A fourth audience, 'communities', as beneficiaries of the firms' CSR initiatives are used to develop a more resilient form of legitimacy that supports the legitimacy developed with the other three audiences.

This paper offers a contribution in three ways. First, it makes a theoretical contribution by the extension of a sophisticated development of legitimacy to explain the use of CSR by the accountancy industry in mediating relations with key constituents. Specifically, legitimacy theory is used to interpret the advent of CSR practice within the accountancy industry and efforts to maintain its legitimacy. In general, prior work documenting CSR and accounting has tended to adopt a bi-polar (legitimate/illegitimate) approach (e.g. Adams, Hill, \& Roberts, 1998; Archel, Husillos, Larrinaga, \& Spence, 2009; Branco \& Rodrigues, 2008; Milne \& Patten, 2002; Momin \& Parker, 2013; van Staden \& Hooks, 2007), rather than considering different levels, forms and temporal textures that occur in the organisational studies domain. In particular, the research evaluates legitimacy through the tri-level lens of pragmatic, moral and cognitive legitimacy conceptualised by Suchman (1995) and associated strategies for legitimacy maintenance. The two 
accounting-related studies that adopt a tri-level legitimacy framework (Georgiou \& Jack, 2011; O'Dwyer, Owen \& Unerman, 2011) focus on strategies for securing legitimacy rather than its maintenance as is this investigation. The more sophisticated theoretical development of legitimacy allows the revelation of the different levels of legitimacy sought and the concomitant strategies used to achieve them in relation to specific audiences (constituencies). Notably, the investigation identifies the problems of achieving the full spectrum of the different levels of legitimacy and the dominance of the least durable and most easily attained pragmatic legitimacy at the expense of more robust but harder-to-attain levels of moral and cognitive legitimacies. An ancillary external audience of 'communities' representing beneficiaries of the firms' largesse is used to develop moral legitimacy. Furthermore, accountancy firms are by their very nature legitimacy agents, conferring legitimacy via public audits of organisations where qualification renders the client's financial statements by virtue of qualification.

Second, the paper offers an empirical contribution by engaging in face-to-face interviews with key organisational actors within the accountancy industry with specific responsibility for CSR. Prior work has examined the CSR communications of the accountancy industry via content analysis (Duff, 2016). However, the nature of public and vocal claims reported in such materials provide clues to two forms of legitimacy (pragmatic and moral), whereas the unspoken nature of cognitive legitimacy means taken-for-granted assumptions will be excluded from such analysis. Furthermore, it offers an insight from each of the four largest accountancy firms (Big Four) and 14 of the largest mid-tier firms. The study represents a comprehensive overview of CSR practice within the UK accountancy industry. Big Four firms typically employ small departments to manage CSR, the largest mid-tier firms may have just one individual employed at manager level to oversee CSR. CSR in most mid-tier firms is part of an individual's portfolio of work which usually includes clients. The intersection of CSR and suppliers of accountancy services is significant as auditing and assurance work, undertaken in the public interest, has been a core service line for the industry for over a century. How firms manipulate and maintain legitimacy with the very publics (audiences) they purport to serve is a topic worthy of investigation.

Third, the findings refine and query elements of professional service firm research that place clients at the apex of key stakeholders. Undoubtedly, clients are conceived as important, but CSR plays as much to the internal audiences of graduates, as potential entrants to the firm and the firms' own internal employees as significant stakeholders. Indeed, CSR was not seen as important to some client groups, particularly private-sector small and medium-sized enterprises, but of greater consequence to charities and public service-sector organisations. In particular, despite the longstanding efforts of some of the firms, short-term pragmatic LMSs prevailed, rather than attempting the critical engagement with public interest issues where the industry has been criticised, such as encouraging tax avoidance or the limited nature of assurance offered. The interviews also highlighted the absence of regulators as a constituent, usually a key pillar of institutional change (Scott, 1995).

This paper proceeds as follows. Section two (S2) provides an overview of CSR, professional accountancy and its UK operating context. S3 outlines Suchman's 
(1995) model of legitimacy which forms the theoretical model for the analysis. and reviews extant empirical evidence. The design, conduct and analysis of the semistructured interviews that constitute the research method are considered in S4. S5 reports the findings. The final section S6 concludes.

\section{CSR, professional accountancy and its UK operating context}

For the purposes of this paper, CSR is defined by the five dimensions identified by Dahlsrud's (2008) widely-cited content analytic study. These five 'defining' dimensions are: environmental; social; economic; stakeholder; and voluntariness. These five categories are also supported in a recent content analysis of UK accountancy firms' annual reviews (Duff, 2016).

The paper draws on O'Dwyer's (2003) distinction between two CSR discourses: a normative approach where CSR is integrated throughout the firm's operations and undertaken for the common good of society; another a business case for CSR where it becomes a means of managing constituents for the benefit of the firm's managers and owners. The business case for CSR has been the focus of much prior academic work in CSR. In particular, significant scholarly effort has attempted to establish the link between CSR and organizational profitability.

Four general types of business case arguments are made: cost and risk reduction; competitive advantage; reputation and legitimacy; and synergistic value creation (Kurucz, Colbert, \& Wheeler, 2008). The meta-analytic studies of Margolis and Walsh (2003) and Orlitzky, Schmidt, and Rynes (2003) identify a positive link between CSR and corporate profitability. The accountancy industry's interest in CSR, particularly sustainability assurance has been to quantify and emphasise the economic contribution of CSR, a process where poor social and economic performers should be penalised by the market and the costs borne by their owners or investors (Malsch, 2013). We would therefore expect business-case thinking to be at the heart of the accountancy industry's CSR philosophy. Business case arguments rely on agency theory, as the adoption of CSR practices is good business practice, opening up new potential revenue streams and allowing the organisation to attract and retain high quality talent.

It is important to understand that accountancy firms now provide far more than their traditional auditing and assurance activities but have developed a coruscating array of service lines, many of which have no public interest element, e.g. the taxation services where the firm plays an advocacy role to reduce their client's taxation liabilities. Significant international political debate concerns the tax avoidance strategies of corporations and the wealthy: facilitated by major accountancy firms' tax advisory services (Sikka, 2010; Sikka \& Hampton, 2005): As taxation funds public services, reducing tax liabilities is a barrier to public service provision and supplementing the incomes of the less wealthy. The past two decades have witnessed the accountancy industry's foray into sustainability assurance and advisory services. Politically and economically the industry has moved to become a guardian of the social responsibility practices of organizations (Malsch \& Gendron, 
2013, O’Dwyer, Owen \& Unerman, 2011; Power, 1997). Their role in sustainability assurance is to reduce social and environmental performance to a market-based logic where poor performance will supposedly adversely affect profits and the market will punish the miscreant (Malsch, 2013). How effective sustainability assurance is in identifying poor environmental performance is open to debate.

The accountancy industry is notable for the scale of its employment and training of graduate talent. High Fliers (2016) identifies that in the United Kingdom (UK) in 2017, professional accountancy firms will be recruiting 4,700 graduates making them the largest employer of graduates, far more than traditional graduate fields such as teaching and the civil service. In addition, firms in the UK are hiring large numbers of school-leavers in addition to the traditional graduate 'milk round'. School-leavers have become attractive for two reasons: first, on the basis of cost with school-leavers hired at two-thirds of the salary of graduates; and second, using a rhetoric of 'business stability' (Duff, 2017) as a school-leaver takes five years to train, whereas a graduate will be with the firm for just three years.

Finally, accountancy firms have an economic, enduring and intimate association with a longstanding and well-established profession. Three of the professional accountancy bodies operating in the UK, Institute of Chartered Accountants of England and Wales (ICAEW), of Scotland (ICAS) and in Ireland (CAI) train large numbers of the graduates hired by the firms annually. The Financial Reporting Council (2016) identifies the six chartered accountancy bodies have some 342,000 members at $31^{\text {st }}$ December 2015 along with a total of 163,000 student members. Each professional body enjoys a membership fee from each student, training income and, on completion of their training, an annual membership fee akin to an annuity. As the vast majority of CAI, ICAEW and ICAS members will have trained in practice, the relationship between the firms and the institutes cannot be underestimated, evidenced by the firms regularly supplying the institutes' presidents and their membership of internal committees where policy is decided. In sum, the accountancy industry exerts a powerful economic and social influence over the profession.

CSR discourse has emerged as an important corporate strategy for accountancy firms over the past ten years in the wake of global reporting crises such as Enron, Parmalat and others. An exploration into accountancy firms' CSR activities is both novel and timely given their implication in the on-going global financial crisis (e.g. House of Lords, 2011; Laux \& Leuz, 2009), with associated demands for greater regulation and competition between firms and removal of potential conflicts of interest (e.g. European Commission, 2011). CSR presents an opportunity for the professional accountancy firm to construct an image of itself as a socially responsible leader in professional services, deflecting attention away from critical commentary on matters such as an on-going financial crisis, regulatory inefficacy and political ineptitude. 


\section{Theoretical framework}

\subsection{Legitimacy theory}

This paper uses legitimacy theory to understand what motivates accountancy firms to engage in CSR. Legitimacy theory has been widely applied in the significant corpus of literature considering CSR reporting (e.g. Adams et al., 1998; Belal \& Owen, 2015; Brown \& Deegan, 1998; Magness, 2006; Milne \& Patten, 2002; Mobus, 2005; Momin \& Parker, 2013; Staden \& Hooks, 2007). Magness (2006 p.541) identifies that:

legitimacy theory has its roots in the idea of a social contract between the corporation and society. A company's survival and growth depend on its ability to deliver desirable ends... ... to the groups from which it derives its power.

Prior study of CSR reporting of accountancy firms (Duff, 2016) identifies that a range of internal and external evaluating audiences are apparent when considering CSR and accountancy. For the purposes of this investigation Suchman's (1995) tri-level legitimacy theory is adopted which is allows a nuanced approach to the internal and external constituents evaluating the firm. Furthermore, recognition that legitimacy evaluations come from multiple sources creates the possibility that legitimacy criteria can emerge interactively between the evaluator and the organisation itself (Deephouse, Bundy, Tost, \& Suchman, 2017).

According to Suchman (1995), legitimacy exists at three levels: pragmatic; moral; and cognitive. In essence, a practice gains complete legitimacy when it becomes institutionalised, where it acquires a state of taken-for-grantedness or acceptance where its absence or the presence of alternatives are unthinkable. Where a practice achieves, such taken-for-grantedness it is said to have achieved cognitive legitimacy.

Suchman's (1995) conceptualisation of legitimacy is nuanced by the existence of different forms (sub-levels). Each form has an explicit temporal nature which can be episodic (transitory) or continual (long-lasting). The focus of legitimation uses an action - essence dichotomy. This division, considers the organisation's desirability and appropriateness, but distinguishes between how it 'operates' (action) and how it is viewed 'in itself' (essence). Each of these levels, forms and temporal natures provide a means of evaluating the organisation and strategies it uses to maintain legitimacy. These are summarised in table 1. Legitimacy theory as articulated by Deephouse et al. (2017) and Suchman (1995) and is much more nuanced in its approach than traditional business case or agency approaches to CSR as legitimacy may be established at three different levels (pragmatic, moral and cognitive) each with various sub-forms, appealing to different constituents and utilising a range of discrete strategies that are dependent on whether legitimacy is being sought, maintained or repaired.

Table 1 here

Pragmatic legitimacy can be conceived of as a simple calculative exchange between the firm and its constituents (audiences). Three forms of pragmatic legitimacy exist. First, 
exchange legitimacy whereby the firm develops practices based on their perceived acceptability to targeted audiences. For example, the firm may calculate the costs of an employee-volunteering programme against the perceived benefits to the employees and the firm. Second, influence legitimacy, where audiences respond positively to the firm because it is perceived to act in their wider interests. Influence legitimacy then often manifests itself as being seen to be responsive to an audience. For example, the provision of a portfolio of service lines that reflect client needs. Finally, dispositional legitimacy allows the personification of organizations, where audiences may perceive the firm to adopt anthropocentric characteristics and creates a strong brand image that presents itself as genuinely concerned for their success and welfare. These beliefs in the firm's personal standing, may allow the firm to endure the periodic failures that affect the accountancy industry.

Moral legitimacy rests on the evaluator's normative and socially-constructed judgement of whether the firm is 'doing the right thing'. Thus, moral legitimacy goes beyond the self-interest characteristic of pragmatic legitimacy. Moral legitimacy is said by Suchman (1995) to be expressed in four forms: consequential legitimacy, reflecting judgements based on outputs or outcomes; procedural legitimacy, where judgements are based on processes and techniques; structural legitimacy, expressed as judgements based on organizational structures; and personal legitimacy, based on evaluations of the individuals leading the firm.

Consequential legitimacy assumes that the practice will be assessed on the basis of what it achieves. However, this may be problematic where outputs and value are difficult to ascertain (e.g. auditing) or where there is perceived to be limited competition in a market (e.g. where the Big Four firms dominate the market for audit and accountingrelated services). When outcomes are less immediately apparent, evaluators focus on methodologies and a concern for procedural legitimacy. Methodological issues are said to be significant in organizations such as professional service firms where certain processes have a ritual value in how society is organised, see for example, Gambling' s (1977) discussion of the symbolic role of corporate reporting and the annual company audit as a form of witchcraft.

Structural legitimacy extends the procedural form of moral legitimacy by identifying how organizational structures serve as a means of signalling a firm's competence to undertake a particular job, especially when outcomes, structures and procedures are not easily observable. For example, the modern accountancy firm may promote its global capabilities, the quality of its people, the breadth and depth of its service lines and investment in technology as badges of trade of the competent professional services firm.

The fourth form of moral legitimacy is personal legitimacy and relates to the personality of the organisation's leaders. The idea is that the charismatic or maverick leader brings their own personal legitimacy to the organisation. This concept is however not strong in the accountancy industry whereby firms are keen to emphasise the quality of the firm and the firm's people on a global scale, rather than individual leaders. 
Finally, cognitive legitimacy reflects the cognitive processes of audiences: the ultimate aim of any legitimacy process. Two processes are evident: how comprehensible the practice is; and how necessary, (taken-for-granted) the practice is. The comprehensibility of the practice is important to audiences who see the world as complex and chaotic. In such instances, individuals need to formulate their experiences into some form of recognisable reality. For example, a professional accountancy firm marketing diverse services may wish to construct a framework of services that organizations can easily identify with: that is promoting comprehensibility and in turn attain legitimacy. Where an organisation achieves a niche position where only one form of organisation may undertake an activity, taken-for grantedness is achieved. For example, only Big Four accountancy firms are expected to undertake large, international audits. Regulatory change encouraging consolidation and large-scale investment in audit technology has prevented mid-tier firms competing in the audit arena. Few would speculate that other financial professional service firms (e.g. corporate bond rating agencies) who might operate a similar business model could possibly venture into this work domain.

Lastly, it is important to identify that pragmatic, moral and cognitive legitimacies cooccur in most organisational settings. Pragmatic legitimacy focuses on self-interest while moral and cognitive levels do not. Pragmatic and moral legitimacies rely on discussion and evaluation, while cognitive legitimacy does not. So, while public exhortations of the organisation's accomplishments may assist claims to pragmatic and moral legitimacy, they reduce the impartiality and detachment needed to achieve takenfor-grantedness.

\subsection{Strategies for maintaining legitimacy}

A central tenet of Suchman's (1995) seminal analysis of legitimacy, is that empirical work needs to consider whether the organisation or activity is seeking, maintaining, or repairing legitimacy. In the current context, the accountancy industry is relatively mature, well-established and supported by an established profession. Consequently, the development of CSR in the professional firm can be considered a maintenance strategy. Studies of maintenance strategies are relatively rare in the literature (Zilber, 2009). Once legitimacy is achieved, maintaining legitimacy becomes a function of the relationship between the organisation and its constituents, rather than the organisation alone. Audiences themselves also become more heterogeneous over time. Therefore, the firm periodically becomes exposed to changing audience demands, with forces such as isomorphism and taken-for-grantedness limiting change and promoting entropy (Suchman, 1995).

Two strategies for maintaining legitimacy concern: (i) perceiving future changes; and (ii) protecting past achievements (Suchman, 1995). Perceiving change strategies require the firm to predict constituents' reactions and foresee emerging challenges. This is said to be achieved by bridging the gap with the cultural environment to understand how audience values, attitudes and beliefs are changing. This information is used to influence various impression management strategies the firm may choose to employ. Bridging efforts are dependent on their relation to pragmatic, moral, or cognitive elements. Pragmatic demands are understood by an assessment of multiple audience 
interests. This might be achieved by enlisting audience participation within organizational decision making providing cultural insights to internal managers. For example, the accountancy industry routinely undertakes research within specific commercial sectors, producing reports which are disseminated to staff and clients alike. To conceive of emerging moral understandings the organisation needs to adopt multiple ethics, perhaps by encouraging organizational members to participate in external normative discourses (Suchman, 1995). For example, the firms' partners routinely serve on technical committees of accountancy professional bodies or working with regulators. Developing cognitive demands requires exploration of multiple outlooks. For example, the consideration of issues of taken-for-grantedness or the comprehensibility of service offerings.

The second means of protecting legitimacy involves protecting past achievements. This can be achieved by converting the temporal nature of their legitimacy from episodic to continual forms. Organizations need to avoid the unexpected that motivates external examination. So, at a pragmatic level, exchanges need to be expected and consistent in meeting audiences' needs and expectations, encouraged a degree of audience control. At a moral level, activities are identifiable as responsible and appropriate. At a cognitive level, stories of organizational behaviour need to be simple so they appear natural and taken-for-granted.

\subsection{Empirical evidence surrounding CSR}

Legitimacy has a significant effect on social and economic exchange: constituents will only engage with a legitimate organisation (Deephouse et al., 2017). The literature identifies four groups that significantly influence the shape of CSR in organisations. These are: consumers (clients), as buyers of a firm's products or services (e.g. McWilliams \& Siegel, 2001; Sen \& Bhattachyra, 2001); managers (partners), as individuals who exercise governance of how the firm's resources are used (e.g. Hemingway \& Maclagan, 2004; Jamali \& Mirshak, 2007); governments, who can encourage or coerce organisations to adopt CSR by the use of regulation or voluntary codes (e.g. Steurer, 2010; Van Marrewijk, 2003); and employees, when talent is a significant determinant of competitive advantage (e.g. Rodrigo \& Arenas, 2008; Rupp, Ganapathi, Aguilera, \& Williams, 2006).

Clients are a significant potential driver of CSR, with a variety of surveys of consumer preferences pointing to consumers' stated interest in CSR (e.g. Vogel, 2005; Bhattacharya \& Sen, 2004), yet social and environmental considerations may only influence a very small proportion of buyers (Vogel, 2005; Schwartz \& Gibb, 1999). In business-to-business (B2B) marketing, CSR considerations are likely to be fewer (Smith, 2008). Steger (2008 p.563) argues that all companies complain about their customers' lack of social and environmental behaviour, yet the company itself will be similarly ignorant as to its own suppliers' conduct. Clients then are 'more likely to punish laggards than reward pioneers' (Steger, 2008 p.566).

Empirical evidence suggests that managers within the organisation are a significant driver of CSR as the agent of the shareholders. This creates an agency problem, whereby managers need to reconcile their own views on moral leadership with a 
diverse shareholder base, some of whom will view CSR as part of the firm's normative core or, alternatively, be convinced by the business case for CSR arguments and others who will view it as a misappropriation of their capital.

Government, as a major transmission belt of isomorphism, also has a role to play in motivating firms to adopt CSR (Vallentin, 2015). CSR can be seen as a division of responsibility between business and government. Thus, business participation in the CSR project is both anti-democratic and impairs market efficiency. Moon \& Vogel (2008) present this division as a dichotomy whereby a utilitarian approach suggests that governments are best placed to serve public policy issues while business is experienced in managing companies. However, government policy and business practice attempts to guide business leaders' actions by the creation of incentives, guidelines and regulation.

According to Moon \& Vogel (2008) government intervention can occur in three ways: first, by the establishment of frameworks for business behaviour; second, by the provision of guidance on best practice; and third, by the creation of partnerships between government and business for CSR, such as the sponsorship of Business in the Community's (BitC) awards and rankings. BitC is an example of what Shamir (2004) terms a market-oriented non-government organisation (MaNGO). MaNGOs are corporate-oriented, or corporate-owned, non-government organisations, that 'through a set of social events, workshops and public ceremonies... ...shape notions such as "social responsibility" and "social change" in ways that are amenable to business and employers' concerns' (Shamir, 2004 p.671). In particular Shamir's (2004) analysis focuses on the role MaNGOs play in integrating CSR within business organisations and shaping the CSR field as one biased towards unenforceable, voluntary and philanthropic effort. Other work that considers CSR frameworks points to developed countries' preference for voluntary frameworks over formal regulation (Sagafi-Nejad \& Dunning, 2008) and that commitment to these standards is frequently slack (Oshionebo, 2009; Smith, 2008; Lim \& Tsutsui, 2012).

The significance of employees in the CSR project is under-researched. Aguilera et al (2007 p.839) identify that 'employees as the unit of analysis have received scant attention in the CSR literature'. Prior studies suggest that CSR is associated with attracting higher quality employees (Backhaus, Stone, \& Heiner, 2002; Greening, Turban, \& Daniel, 2000; Huselid, 1995; Pfeffer, 1994; Turban \& Greening, 1996). Therefore, accountancy firms with a constant requirement for large numbers of highly-educated employees should benefit from appearing as attractive to prospective job applicants (Orlitzky, 2008).

Beyond the academic literature, the extent to which organisations encounter demands to demonstrate social responsibility remains questionable. It seems that the demands are sporadic and spontaneous. For example, 2011 saw indignant protests against capital by movements such as Occupy and UK Uncut and encountered significant rioting and public disorder across the UK. Similar protests have occurred in other jurisdictions, especially the United States of America (USA), 
where Occupy has been active. More recently, significant political debate at an international level has focused on tax avoidance strategies of mega-corporations and wealthy individuals and the role major accountancy firms play in these schemes.

Finally, it is important to realise that all business organizations face varying degrees of social evaluation from a range of evaluating audiences. The accountancy industry is said to be evaluated by clients on the basis of their communication strategies (Hodges \& Young, 2009; Stone, 2012). How the organisation is perceived then becomes a significant issue for its managers. In accountancy firms the effect of these perceptions should be magnified given: (i) their public interest role as independent agents of investors and society at large in the auditing of clients' financial statements; (ii) the advocacy service offered in relation to tax compliance and negotiations, whereby they act as intermediaries between an individual or corporation and the tax authorities; and (iii) their function in quasi-financial regulation. Collectively these factors should result in their activities coming under increased public scrutiny.

\section{Methodology and data collection}

\subsection{Background}

The accountancy industry is dominated by a status group of four large firms: the 'Big Four' of PwC, Deloitte, KPMG and EY. Consequently, the industry is characterised by extreme market concentration where the largest firms control audit and assurance services delivered to international corporations. For the purposes of this study, firms are classified in terms of their fee levels, using data available from industry journal Accountancy Age. The financial characteristics of the largest firms at the time of undertaking the interviews are illustrated in table 2. The industry's structure means in terms of fee levels there is a large gap between even the largest mid-tier firm and the smallest Big Four firm (EY). Fee levels also notably drop between the firm ranked 11 and the firm ranked 12. For the purposes of this research three categories are used: (i) 'Big Four' firms; (ii) 'upper mid-tier' firms ranked 5 to 11 by fee levels; and (iii) 'lower mid-tier' firms ranked 12 to 20 by fee levels. These divisions reflect the resources available to each firm and their ability to compete on a national and international scale.

\section{Table 2 here}

In pursuit of its aims, the paper employs a qualitative methodology undertaking 23 semi-structured interviews conducted with senior personnel responsible for CSR activity within UK accountancy firms. All 23 interviewees were from 18 different accountancy firms and interviews were arranged by contacting the firm directly. Firms were identified from publicly available analyses of fee income. The nature of the personnel interviewed is relatively heterogeneous reflecting the diverse structures employed within large professional accountancy firms. Interviews were arranged with 17 of the largest 20 firms as classified by fee income in the 
UK and one firm ranked in the 21-30 fee level category. Each of the 11 largest accountancy firms in the UK were interviewed, i.e. all Big Four and upper mid-tier firms were interviewed for this research. Six of the remaining seven firms interviewed were located in those firms ranked 12 to 20 . The residual firm interviewed was lies within the 21-30 ranking by fee income category and chosen because it was suggested as an exemplar of CSR activity by some of the larger firms.

The CSR functions are small and typically employ few staff. In the Big Four firms, the CSR operation will consist of just a handful of individuals. In mid-tier firms, CSR was the responsibility of just one person or more typically, it was within the portfolio of often a partner or director with other duties, such as clients or practice management. Interviewees therefore represent a large sample of the population of CSR workers within the accountancy industry. Interviews were sought in each firm with the person whose responsibilities were, or included, the CSR portfolio. In three instances, other relevant organisational actors were identified who were subsequently interviewed. The respondents therefore spoke authoritatively and formally on behalf of the firm. Participants were however encouraged to speak openly and express views beyond their firm's extant policies and beliefs. Given the relatively large number of firms spoken to and the small size of the CSR functions within the firms it is reasonable to suggest that the findings of this research are representative of the accountancy industry and provide a comprehensive insight into CSR practice and philosophy within the sector.

Initial interviews focused on mid-tier firms and then moved to smaller firms to establish whether CSR was being actively considered by smaller firms as searches of their websites and external communications suggested CSR was frequently given little prominence, in contrast to the confident, bullish displays provided in Big Four firms' annual reviews and their marketing-related literatures. In the accountancy industry visible CSR is the domain of larger accountancy entities and the 18 firms interviewed provide a comprehensive of accountancy-related service firms and CSR.

\subsection{Data collection and analysis}

In total, 23 individuals were interviewed, with some firms extending an invitation to interview other individuals who might be more knowledgeable about certain aspects of the CSR operation. Table 3 lists interviewees' job titles, with some homogenization of these to assist anonymity and their firm. Big Four firms maintained a small CSR function with a small core of CSR staff. In the largest upper mid-tier firms this would typically be confined just one individual. In other upper and lower mid-tier firms CSR would be the responsibility of an individual who typically had other duties. For example, in a smaller firm it would be the responsibility of a managing partner or chairman. The population of individuals directly concerned with CSR is then relatively slender.

All interviews were conducted in the interviewees' own offices. Interviewees were initially contacted by telephone, followed up by email. A follow-up email was also sent to participants articulating that the broad aim of the research was to elicit an understanding of the motivations for the firm adopting CSR and the 
potential complexities that arose from the viewpoint of the firms themselves.

Interview questions addressed two interrelated issues(i) target audiences for CSR; and (ii) what motivated firms to engage in CSR. The first question was designed to elicit a detailed understanding of the groups to whom CSR was seen as relevant. The motivation question extended to an examination of the relevant constituencies identified and the significance of CSR to these stakeholders.

Table 3 here

Typically, the interviews lasted between 60 to 90 minutes. Each interview was recorded using a digital dictation device and subsequently transcribed by an expert transcriber independent to the author using guidelines suggested by Poland (2002). Typically, interviews elicited some 12 to 15 pages of transcriptions. Field notes were taken during the interviews, along with a reflective log created after the interviews had taken place. All transcriptions were sent to the individual interviewees for confirmation.

Before the start of each interview a statement of the objectives of the project and a list of possible discussion points and questions were given to the interviewee. Consistent with the extant accountancy literature, the questions posed to interviewees were designed to be of an exploratory nature, offering descriptions, interpretations and some explanations for the motivations for undertaking CSR and the potential conflicts that could arise from CSR activity. There was a conscious effort on the part of the interviewer not to influence the respondents' views with personal perspectives. The participants were not restricted to these topics but instead were encouraged to expand on other issues that they felt were important. Interviews were conducted on a strictly confidential basis and interviewees were assured of the anonymity of their responses.

The interview data were analysed using Saldaňa's (2009) three-stage coding process. The first cycle coding involves careful reading of each transcript. An analytic memo, or reflective log, of initial thoughts is created (Terry, 2016). This thematic analysis is used in two ways. First in a bottom-up data-driven manner to establish what is in the data, but also in a 'top-down' fashion to allow the exploration of particular theoretical ideas (see Braun \& Clarke, 2013 p.178). Each transcript is re-read to create initial themes suggested by the data. Field notes along with publicly-available data, such as annual reports and on occasion CSR reports, available for each firm interviewed, were read alongside the transcribed interviews. The objective of this first cycle coding is to identify common and significant themes which support or militate against the theoretical categories or suggest new categories. Second cycle coding involves re-organising and re-analysing the first-cycle data codes (Saldaňa, 2009). Linkages between the principal themes were sought at this stage. Finally, these themes were related to each of the identified constituency groups and in terms of the LMSs adopted by the firms for each group. 


\section{5. $\quad$ Findings}

Consistent with prior literature (Pruzan, 2008; Waldman, Siegel, \& Javidan, 2006; Williams \& Aguilera, 2008) and the tenets of legitimacy theory, the motivations for undertaking CSR activities directly related to those audiences that the firm wishes to engage with. An inductive analysis of the interviews revealed that firms identified four categories of constituents for whom CSR was believed to be significant. These are broadly in terms of identified significance: (i) clients; (ii) prospective graduate entrants; (iii) internal (existing employees and partners); and (iv) communities (other non-client external constituents). Motivations for engaging with CSR discourse are considered for each of these four audiences. These are described in the following section and summarised in table 4.

Table 4 here

\subsection{Maintaining legitimacy with clients}

The legitimacy being maintained with clients resembled a form of pragmatic legitimacy. Strategies are utilised that attempt to meet the policy needs of its client constituency, while attempting to influence existing and new clients by sponsorship or pro-bono initiatives. Clients were classified for CSR purposes into discrete sectors, for example, by size, ownership type and industry; rather than by the types of services they buy, for example audit or taxation services.

Clients were significant in terms of the perceiving change LMS, with many interviewees viewed CSR as a precursor to doing business in a changing marketplace where it had been perceived as a business imperative:

I think it's really important to the business and I think we need to give it a much higher profile. So, we do lots of things and I'm happy to go into what we do. I don't think we give it the profile internally that we should do... I am going through a process to really turn up the volume on Corporate Responsibility. So, it is important. It's important to the business. It's important to me, personally and I want the business to take it a lot more seriously over the next few years. Sorry, I don't mean I'm going to leave it a few years. I mean starting right now. (case 18, firm 13)

However, it was questionable how critical clients were in their evaluation of firms' CSR policies. For example, some of the firms' policies were brief and perfunctory. Nonetheless, adopting some form of CSR strategy was seen as necessary in the current financial services environment and all firms interviewed reporting as having some engagement with the concept.

The Big Four firms had adopted a responsibility framework provided by a MaNGO, namely BitC's Four Pillars of CSR: communities; environment; ethics and integrity; and human resources. BitC then acts as a legitimacy agent that both: normalises, by defining CSR; and authorises, by mandating CSR. In some instances, the Four Pillars 
was rehashed into some other variant created by the firm that mapped onto the (e.g. a CSR wheel). These efforts are devices to attempt to secure a client's trust that the firm operates in both the client's and society's best interests. One of the firms interviewed was one of two corporate partners that had developed the Four Pillars model (then called Winning with Integrity) for BitC in 1991 . Such discursive devices could be used to win business:

And then around how do we deal with our clients from an ethics perspective, that goes without saying that we comply with all the laws but actually it's about choosing to go beyond those in terms of some of the services that we provide or the way that we engage with clients, the processes that we would go through in order to accept a client and that kind of thing. So, it's a very broad picture of what you would do to be a responsible organisation across your whole business, addressing all of your stakeholders. So, I think if you kind of take that as that's why you do it, it just makes good business sense. It can give you competitive advantage and particularly at the moment there's obviously a massive issue around trust in the business world and actually demonstrating that you're going beyond the legal minimum is around building trust again and that kind of stuff so it really is for the good of the business. (case 9, firm 6)

Clients themselves were heterogeneous, a sectorial grouping with sectional interests. CSR as an LMS focused on perceiving future changes by monitoring multiple audiences, an identification of who their key client audiences were:

CSR was becoming more and more the thing to actually get recognised for and 2 increasingly in terms of our business, we work within the public sector, we work with, we've got a very strong presence in charities in terms of some our specialist services we provide and one could see that if we were going to be able to continue to exist in those sectors and develop our business into those sectors, we as a firm ought to be making much stronger statements around that. (case 15, firm 10)

I suppose, from a client point of view, increasingly we were noticing that for tenders it was an expectation, particularly for larger blue chip clients and the public-sector clients that they would not understand our approach to corporate responsibility and I suppose previously we would also always take a sort of local office approach so each office did what it wanted to do. But then if you're trying to bring that together and try to demonstrate what the firm does nationally, that's quite difficult. So, I would say probably two to three years ago was when it seemed to be coming to the fore from a client perspective. (case 11, firm 8)

We have lost 2 or 3 tenders in that on the basis of that and I think that's probably, that was probably the switch, you know, the last straw that broke the camel's back or whatever the right phrase is, but actually it's more because we see ourselves as emulating leading best practice. This is seen as leading best practice and you need to be seen to be doing it to be able to compete and it's about that. At the end of the day the fact that it has a good impact on the environment is secondary almost I'm afraid... (case 16, firm 11)

Each of these interviewees identified the significance of CSR to discrete clienteles, in particular the public sector, larger high-profile for-profit companies and charities. As case 16, firm 11 suggested, CSR is necessary to compete in certain sectorial arenas. In terms of organisation, as case 11, firm 8 indicates, CSR was usually a firm-wide function. CSR activities were typically designed to support the firm 
rather than promote particular service lines. In smaller decentralised regional firms, responsibility passed to individual offices, rather than operational divisions or services lines such as audit or tax. Similarly, CSR did not feature in the promotion of services like audit and assurance or taxation that have been under threat in recent years as a perceived consequence in their role in the global financial crisis, or of firms' role in aggressive tax avoidance schemes shifting the burden from rich corporations and wealthy individuals to the middle classes.

For example, one smaller firm had established a charitable trust to channel its charitable activities, with a view to consolidating relations with their charitable clients:

We do work quite a lot in the charity sector, the not for profit sector, so where we are in the $25^{\text {th }}$ year now I think in the Accountancy Age order through turnover, if you looked at firms that specialise in not for profit we would probably be number eight, including the final four. And so for some time the conundrum of doing so in our position was we wondered what our clients would do and would we have lots and lots of applications for money from the charitable trust that we set up. (case 23, firm 18)

The issue of monitoring multiple audiences arose in assessing different attitudes to CSR. When blue chip companies, charities, government contracts, the public sector, or NGOs were not part of a firm's client base, then CSR would have a much lower focus. For example, in the case of owner-managed small and medium-sized enterprises:

The market place under managed business is not concerned about CSR. (case 20, firm 15)

The following lower-middle tier firm narrator described the position succinctly, emphasising the importance of client service, accessibility and expertise were paramount relative to the symbolic nature of CSR activities:

I think it would be more internal PR and prospective employees, in terms of graduates, rather than prospective clients but I still think it's not a major issue for owner managed businesses, they're much more keen to know about your level of expertise in their specific sector and how accessible you are as a partner. They can always get hold of you no matter what time of day and how quickly, how proactive you'll be and things like that. It's those kinds of burning issues that still come to the forefront compared to who got the Dragon Award or something like that. (case 22 , firm 17 )

In such instances, clients could be sceptical about the CSR project, to the extent that employing CSR discourse could be counter-productive. In this sense, the legitimate sustainable organisation became financially illegitimate by virtue of its perceptions of building environmental costs in that needed to be passed onto clients:

The one thing that would, well it probably would trickle down or should trickle down to our fees is that we have been a carbon neutral company and we have had questions from clients around, does that mean part of my fee is going to offset the carbon and things, for the work that you undertake for me? Some are very 
happy about that and some say, you know I actually I would like the choice to pay for it or not. As the case may be. (case 8, firm 5)

The second LMS identified is protecting past accomplishments. In terms of CSR actions, philanthropy in the form of sponsorship of events or pro bono activity was frequently highlighted across all categories of firms. For the middle tier, pro bono activity was a key means of influencing client groups. Firms in this category viewed themselves as 'brains businesses' (case 16, firm 11) where their expertise in financial matters represented their greatest asset and the best means of 'giving something back' (case 17, firm 12). For larger firms, a visible presence in CSR could create a certain credibility among prospective clients:

The client had come in on [name of well-known day of national charitable event] just because he happened to have a meeting in the office that day and we were doing abseiling down the outside of the building to raise money and that kind of thing and the person who was talking to them hadstarted to talk to them about some of the community work that we do. He had said yeah, yeah, I know you do all that stuff, I can see it in your people. (case 6, firm 3)

what our clients get from us, our product that we sell to them is our people and I would say they benefit [from CSR] perhaps in the sense of more rounded person that we're selling to them. And somebody's had the opportunity to look at different ways of training for instance. They have been able to use their volunteering for whatever, whatever they've needed to develop, so that's one way I think they benefit. (case 8, firm 5)

Overall, considering client audiences, pragmatic levels of legitimacy are highlighted. This occurs in an exchange form, whereby firms adopted a policy for the sake of needing a policy to be considered for tenders, particularly in the public sector. Influence forms were evident of occasion when a firm provided sponsorship of an event or some probono support. A firm that demonstrated responsibility 'became a very hard act to follow' (case 11, firm 8). Typically, larger firms used branding, corporate communications and reporting, which are more voluminous in the largest firms (Duff, 2016) and lend themselves to pragmatic and moral levels of legitimacy.

\subsection{Maintaining legitimacy with graduates}

Graduate entrants who enter the firm as trainees were highlighted as being influential in firms' CSR thinking; all interviewees made some reference to this constituency. Although firms continually hire experienced qualified individuals, graduates are traditionally hired in large numbers. Accountancy-related professional services are the largest employers of graduates in the UK, with over 4,700 vacancies forecast in 2017 (High Fliers, 2016). The size of the cohorts often means two intakes may be recruited each year in the Big Four. Attrition rates in professional accountancy training are high with firms indicating that $90 \%$ of an intake will leave the firm within five years. This reflects factors such as demanding professional examinations, the need for long-working hours and the existence of many other alternative careers to highly-qualified accountancy workers. As one Big Four narrator identified: 
We have to recruit 1,000 people a year you know and unless we are offering them a workplace in which they can thrive in, they're not going to come and work for us. (case 6, firm 4)

The type of legitimacy maintained with graduates, as potential employees of the firms corresponds to a pragmatic level of legitimacy. Firms aim to influence the career choices of graduates and make them more favourably disposed towards the firms by suggesting that they share their values and operate in their best interests: a form of dispositional legitimacy.

In terms of LMSs, perceiving change was focused on a changing economic climate, from a scarcity of well-qualified applicants to a temporary glut of applicants in the face of a sharp decline in competing, lucrative positions in investment banking. For the Big Four firms securing the 'brightest and the best' talent was believed to be critical to justify their market position and higher fee structure, despite the ongoing economic crisis and wide-scale graduate unemployment. Despite an abundance of graduate applicants there remains a scarcity of the 'high-flying' talent larger firms seek.

For each of the Big Four firms, CSR appeared as an important element of their graduate recruitment and each offered a small block of time, typically a day or half day that employees could spend undertaking voluntary work in the firm's time. Issues of time, time-keeping and the need for physical presence have long been emphasised in the literature documenting working practices in the accountancy profession where staff keep time sheets recording their activities or billable time down to 15 minute intervals. The value of the volunteering inducement has to be set against the high levels of commitment required by many staff including working away from home and for long hours (e.g. Kornberger, Justesen \& Mouritsen, 2011).

And our flagship policy is our community policy where we give everybody six days a year for volunteering and we get a lot of people come through and say actually I've looked at your six-day volunteering policy and that was why I chose you. Now they may never use that six-day policy, they may never take it up but it just tells them something about us as a firm. Something that they like - and that's why they choose us. (case 8, firm 5).

Relatively little 'street cred' accrues to the highly-qualified graduate who joins an industry with a relatively poor stereotypical image and one which is regularly censured by negative commentary for its role in financial scandal and servile service to capitalism. A visible responsibility discourse, communicated in the right places provides some means of ensuring that firms convince their graduate constituents that they act in their best interests and of society as a whole.

For some mid-tier firms, graduates' demands for CSR were found to be vexing by some firms' management boards. These requirements frequently highlighted where the firm lagged in comparison to other firms and professional service providers. This was particularly the case when the firm had little CSR profile by 
believing clients to be apathetic to CSR:

The CEO finds younger people putting him on the spot about CSR. Think it's an issue we seriously need to address but haven't found out how. (case 22, firm 17).

Firms differentiated graduate hires from experienced recruits. Significant differences were identified by firms between the aspirations and ideals of newcomers, compared to longstanding employees or experienced hires, creating a generation gap. For example:

The people that we employ from university now, you know, we've gone through generation $\mathrm{X}$ into generation $\mathrm{Y}$, they have a different mind-set. A different set of values to the ones that the 40 year olds and the 50 year olds who are running the businesses have and corporate responsibility is critically important to those guys. (case 18, firm 13)

Well graduates have always been a big target for us... I think when I first started this it was always viewed as the older generations didn't really get, you know, business was business and you didn't really mix the two but I think over the last four years I've really seen a shift in that and I started to hear things like 'oh my children are looking at this at school and they're very interested' and parents started to become interested, who are also employees, started to become interested in it and I think now I'd say, actually, the wider pool of talent is looking at CSR as a differentiator so it's not just graduates any more. It's a differentiator for all. (case 8, firm 5)

However, there was evidence of the existence of multiple outlooks. At one end of the spectrum, a minority of interviewees perceived graduates to be disinterested in CSR:

[CSR] is an IPW [Important Persons Whim]... I have a very healthy amount of scepticism about why graduates are actually asking those questions [about CSR]... or is it just that their careers advisers are saying this is what you ought to talk about and they can't actually think of anything else to talk about so therefore it's a good question to ask. (case 11, firm 8)

Another mid-tier firm had undertaken some market research using students to develop its approach to CSR emphasising the importance of this audience to the firm:

In terms of the research that underpinned our approach to corporate responsibility we actually used an undergraduate team from [Name] University. So, one of them was a student that had done a work placement with us, they were required to do a final year research project. We knew we wanted to have a look at corporate responsive so they did a chunk of research for us that looked at what was going on in the market place, our competitors. They did some desk-based research into what our clients' websites were telling us about their approach to corporate responsibility, as well as some of our sort of top targets. We talked to a number of employees around focus groups. We went out to universities to ask them about their thoughts about corporate responsibility and to what extent it was a decisionmaking factor for them in choosing potential employers. (case 10, firm 7) 
Overall, the process of maintaining legitimacy with graduate audiences arises from largely pragmatic sources. In terms of pragmatic legitimacy, influence and dispositional forms are highlighted. Firms seek CSR strategies that appeal to members of a graduate audience who believe the firm's actions will be in their wider interests. In particular, firms merge training and development issues with wider aspects of CSR. So, volunteering, which the larger firms emphasised, became a form of team-building, socialising and learning new skills. Dispositional forms of pragmatic legitimacy are evident also as CSR becomes a means of creating an image of integrity, distant from previous financial scandals involving accountants and auditing.

\subsection{Maintaining legitimacy with internal audiences}

Internal audiences, comprising existing partners and staff, contrast with the external audiences of clients, graduates and communities. Firms are rich in human capital and its knowledge workers are powerful, as dissatisfaction with the ethos of the firm, or its working conditions can lead to resignations and the pursuit of alternative employment. As described earlier in this paper, staff turnover is particularly acute after qualification, where newly-qualified chartered accountants depart for more (intrinsically or extrinsically) rewarding employment.

For internal audiences, CSR is portrayed as something valuable to their individual interests and their collective stake in the firm respectively. A Big Four narrator illustrated the point, linking the BitC's four pillars and the business case for CSR back to internal constituents:

So very much around the four pillars. Workplace, how do we deal with our people, how do we treat them, how do we develop them as individuals, how do we enable them to work in ways that suits their personal needs. So, flexible working and things like that. How do we look after their health and well-being? You know all this stuff has got a balance between it's good for the business and I think none of us should pretend that being corporately responsible is for altruistic reasons or you know for the good of our souls. It's not; it's about commercial realities and making good business sense. So, from a people perspective if you've got healthy good employees, their sickness goes down, you've got a better productivity and happier workforce so that's got to be good kind of thing. (case 6, firm 3)

That is, firms are engaged in a LMS of perceiving future change by monitoring multiple audiences. The volunteering activity becomes a means of building bridges both between the individuals and external audiences but between the firm and the employees too. For the majority of firms actively engaged in CSR, firm 6 encapsulated why this activity had become increasingly important for firms:

the biggest benefactor is our people for the opportunities for fun and teamwork and you know feeling good about what they do. In reality, they're the biggest. So, when our average paper goes down from 14,000 sheets per person to 1,000 per person it doesn't really help the environment a huge amount but it helps us feel that we are doing something. (case 9, firm 6) 
The popular image of accountancy work does not emphasise fun and, perhaps for some individuals, creates an escape or sense of variety for them in their everyday work. The teamwork provides a collective dimension and creates a 'feel-good' factor. CSR became a way of uniting the firm in a common direction, improving the quality of teams and allowing junior staff to exhibit leadership. Overwhelmingly, the firms' people appear as the most important CSR constituent, although this is not apparent from the firms' communications where the communities audience is emphasised (Duff, 2016). For those firms at the bottom of the CSR adoption curve:

CSR is seen as a bonding activity for staff. (case 13, firm 9)

In smaller firms where resources and overheads are tight:

People aren't forced to do particular things. People work very long hours. People may want to do things anonymously. Volunteering gives it a strong identity within the firm. (case 4, firm 2)

Overall, the process of maintaining legitimacy with internal audiences arises largely from the influence form of pragmatic legitimacy. Firms develop CSR activities that appeal to 'our people's' wider interests. This is particularly the case in trying to foster an image that the firm works in the best interests of the wider community, rather than a sole focus on partner profits.

\subsection{Maintaining legitimacy with other external audiences (communities)}

The final audience identified by interviewees was that of other non-client external audiences; these were usually presented as 'communities'. This grouping frequently represented individuals and groups that lived in the locality of the firm and visible beneficiaries of the firms' CSR actions. For example, Big Four firms PwC and EY are located in elegant waterfront city offices at Moore Place in the London Borough of Southwark, a relatively poor district that neighbours the enormously wealthy and influential City of London financial district.

The communities' world provides a source of moral legitimacy and as such offers a more enduring and robust form of legitimacy than the pragmatic legitimacy established with the client, internal and graduate worlds. In particular, the consequential form of moral legitimacy is highlighted by the largest firms in the highly-quantified and reported engagement with communities that demonstrate the firms' CSR achievements. Communities become a visible and tangible target of the accountancy industry's social engagement.

Significantly, communities exert relatively little influence on the firm as they can neither withdraw their labour nor patronage. In particular, communities, local organisations and charities feature frequently in awards ceremonies. These awards provide a visible means of allowing the firm to be positively evaluated for some measure of its social performance. 
In terms of LMSs, the communities' constituency is used as a means of protecting accomplishments. For example, an image that was often created when reading the firms' annual reviews and other communications was the business of painting schools or local nurseries (Duff, 2011). Even anecdotally, when mentioning CSR to accountants working in practice, the image of CSR is that of teams of professional accountants volunteering to decorate the local primary school, a visible means of instantiating their commitment to others less fortunate than themselves. Only one interviewee (case 15, firm 10) positively identified the stereotypical idea of 'painting gardens' as a CSR activity. For other respondents, this form of volunteering activity was often considered as either jejune or comedic:

Other firms go off and do something, finish; they gather in a City boozer covered in paint and get trolleyed. (case 14, firm 9)

The interviews suggested that community involvement had become more pervasive and complex since those team-building volunteering days, where participants undertook relatively unskilled manual work as a means of 'putting something back'. Volunteering itself was significantly funded, but had to be focused on community issues of strategic importance to the firm:

[Name of Leader]'s doing the right thing for our clients, our people and our communities. Communities right up in the forefront... Everyone gets 3.5 hours per month to do a community or CS [corporate sustainability] activity [which]... must be around education, employability, or environment. (case 6, firm 3)

The Big Four have established a benchmarking group, the London Benchmarking Group (LBG), which allows individual firms to compare themselves to others within their peer group. The LBG operates in two ways. First, as a means of protecting against potential legitimacy miscues (Suchman, 1995 p.595) and second, in recognition of the Big Four status group, an honorific grouping where each benefit from, or are tarnished by, each other's social evaluations.

It's unfortunately called the London Benchmarking Group. It is a global methodology. It's the best methodology, noticed best practice model to use which way you measure inputs, outputs, impacts, you can actually measure and over the years it's evolving. It used to be mainly on inputs, what are you putting in but now it's like what's your impact. It's alright saying you've got 100 mentors out there but what effect are they having? So, we are doing a lot of measuring of our impact and that's increased over the past two years. (case 7, firm 4)

Other large firms were members of a corporate responsibility group (CRG) with other businesses to create a 'peer learning network' (case 3, firm 1):

In a nutshell, the Corporate Responsibility Group or CRG was set up in 1994 by six community managers in different businesses as a way of sharing best practice. At that stage, the ambition was to grow to 30 businesses because it was felt that that would be a manageable number and it was a huge ambition to have from the six people who sat round the table... CRG now has 89 businesses in 
membership and it's the business that is a member rather than the individual. So [name of firm] are members but I support it by CRG as a learning and development network. So CRG runs about 12 events a year which are personal learning pieces, operates under Chatham House rules and doesn't allow any consumptants or any external people, so it's a safe place for a CSR professional to operate in really and it's where you can ask the awkward question. (case 7, firm 4)

The LBG benchmarking group focuses on policy and methodology, with the corporate responsibility group addressing issues of staff engagement. At face value, these networks perform a role allowing the firms to 'share ideas' (case 7, firm 4), for example, 'managing regional office champions'. At times, they act collectively where the group's rapporteur negotiates a more competitive deal with organizations they mutually sub-contract to run particular CSR services, for example, managing volunteers, using their collective status to create economic leverage. Consequently, the benchmarking group has an active, rather than passive, role in determining firms' relations with outside parties.

At the same time, community work had become more strategic with a focus away from pro bono and discounted audits to leadership programmes where teams are created to assist a cause of some strategic value to the firm. Therefore, in terms of the protecting accomplishments LMS, firms sought to curtail highly visible episodic strategies to subtler, continual strategies.

For smaller firms, a less long-term approach was evident and community involvement tended to be more serendipitous. Pro bono was considered effective when the work allowed the firm to be seen in a positive light by a trade association or a community group, for example:

The firm is a market leader in the shipping industry... We had a lovely case that got into the press last week where we had spotted in a newspaper called Lloyds List which is basically the shipping daily newspaper. In their diary section on the back page a chap in Dover who was involved with something like the Dover branch or the Kent branch of the Merchant Navy Association and there is a statue in Dover where there had been a VAT problem and they had to pay $£ 6,500$ in VAT and we spotted it. So, we got in touch with the Lloyds List Editorial team whom we know quite well and said, I think we might be able to solve this. So, one of our VAT guys went off and solved it and they got their $€ 6,500$ back and it was reported in Lloyds List last week. (case 12, firm 9)

In particular, firms frequently linked community engagement to staff engagement:

And we also do things like volunteer at Christmas in [name of charity] shops; lots of our volunteers go in. We've done significant pro bono projects for both the [name of charity] and [name of charity] because of their charity partner status and how we've helped them look at all sorts of issues they've got right across our different service lines. So... it's important to us that any, it's one of the criteria in fact that we really look at, any charity partner has got to provide not just opportunities for us to fund raise for them but lots of opportunities to get our people engaged and volunteer and use their time and I think that's kind of going back to the philanthropy point we were making before, we're really focused on it not just being 
cash transactions where we're dealing with any kind of third sector organisations, there's got to be a partnership and that's the only way we get well strong engagement for our people, raise more funds as well. You know it's a kind of virtual cycle really. (case 6, firm 3)

\section{Discussion and conclusion}

This paper aims to offer a theoretical and empirical interpretation of the means by which accountancy firms use CSR as a way of maintaining legitimacy with significant constituents. The paper then complements prior research that examines the social and environmental communications of professional accountancy firms (Duff, 2016) and the small but growing accumulation of literature that documents sustainability assurance (see Malsch, 2013 for a review). The key audiences were identified as: clients, as firms' remunerators; graduates, as potential employees and future partners; the internal stakeholder of existing employees and partners who create and service work; and an ambiguous external stakeholder of communities, the beneficiaries of the firms' philanthropic efforts. Summary findings are shown in table 5.

Table 5 here

The literature review suggests the key evaluating audiences that drive CSR are customers and managers. The findings of this investigation indicate the firms' managers (partners) are less to the fore, but the firms' current and prospective employees are prominent drivers of social responsibility discourse. Firms chose to differentiate between potential hires and those already working within the firm. Essentially new and experienced hires represent the same stakeholder group yet are separated by the firms' recruitment operations. So, firms divide the two parties by their commitment to the organisation.

Suchman (1995) differentiates between strategies for seeking, maintaining and repairing legitimacy. The interview evidence gained from 23 participants in 18 large UK accountancy firms overwhelmingly points to CSR being used as an LMS, rather than a means of repairing legitimacy in the event of crisis at firm-level or industry-wide. There was no evidence of CSR having been developed in response for example to either the corporate financial reporting scandals of the early twenty-first century or the global financial crisis of 2009. However, in some instances CSR could support the process of seeking legitimacy with new clients and CSR teams were included as part of the tender pitch in these instances. This supports prior research considering sustainability assurance whereby the CSR teams became a first point of contact in the process of a sustainability assuror seeking legitimacy with a new client (O'Dwyer et al., 2011).

A theoretical contribution is developed by the use of a tri-level multi-form framework of legitimacy. Specifically, it considers the levels of legitimacy created with different evaluating audiences and more subtlety the different sub-forms of legitimacy developed. Initially, firms' CSR practitioners focus on a process of maintaining pragmatic legitimacy with clients. Considering clients, legitimacy focuses on two forms: exchange and influence. Exchange forms dominated where CSR had become an antecedent of doing 
business in particular with certain sectors needing a CSR policy. Influence forms were apparent in some but not all firms and tended to be instantiated by means such as adopting a CSR framework developed by another legitimacy agent for example, BitC, as a means of attempting to demonstrate how the firm is of benefit to constituents' wider interests.

Similar forms of pragmatic legitimacy were negotiated with the external world of graduates and an internal world of existing employees and partners. In relation to graduates, influence forms were apparent using recruitment literature and a steady stream of references to various social awards and employer rankings for training and employment. A dispositional legitimacy arose where the presentation of CSR allowed the personification of the organisation as possessing values, tastes and other anthropocentric attributes.

Internal audiences are generally less studied in the legitimacy literature (Momin and Parker, 2013) and also described as fragile and tentative in their approaches (Brown \& Toyoki, 2013; Erkama \& Vaara, 2010). In a similar vein to the external, graduate world, pragmatic legitimacy corresponding to an influence form was identified whereby the firms' engagement with an external non-client world was for some internal constituents enriched their identity as members of the firm. However, for some the benefits of this activity were almost nil. Respondents frequently characterised this as a generational gap between generation X cynics and more idealistic millennials. Whether in practice this dichotomy actually exists is debatable.

The key rhetorical device used with the internal and graduate audiences was the existence of the communities constituency. In some ways, communities don't comprise an audience as in many ways they don't evaluate accountancy firms as they have little interaction with the financial world, they ae relatively powerless having little regulatory influence or authority, cannot withdraw their custom or labour. Communities are valuable in a CSR context as they allow the production of something corresponding to moral legitimacy. Moral legitimacy is both more robust and more difficult to establish than the forms of pragmatic legitimacy sought with client, graduate and internal constituents. The consequential and procedural forms of moral legitimacy are highlighted. Consequential legitimacy is represented by the wide-scale engagement with external legitimacy events showcasing CSR and voluminous reporting of CSR (Duff, 2016). Procedural legitimacy is demonstrated by the use of techniques such as the BitC's four pillars of corporate social responsibility. This legitimacy then underpins the pragmatic legitimacy forged with the key clients, graduates and internal constituencies.

What is interesting is what is missing in the accountancy sectors' interpretation of CSR. Institutional theory suggests the State as a major source of institutional behaviour (Scott, 1995). It might have been expected that participants would have identified the State or regulatory authorities as a significant constituent. This expectation has been amplified by the continued discussion of the implication of audit in the current financial crisis and the role of the firms in aggressive tax avoidance schemes and the growing disparity between rich and poor throughout the world (e.g. Sikka, 2009). However, neither of these constituents was apparent from the 
interviews, which supports the view that CSR is a means of managing evaluations from present and future employees and clients than an exercise in political power.

This investigation has four limitations which are suggestive of future research. First, the methodological approach adopted of interviewing all the large firms and most of the medium-sized firms creates a form of CSR survey. Future analyses would benefit from a case study approach of a single firm that allowed the views of multiple organisational actors including external parties such as clients and prospective employees and community participants in the CSR project. Such an approach would be able to more finely examine the interplay of different legitimation strategies with key audiences.

Second, the future of CSR and accountancy firms appears uncertain. Although firms have been reporting CSR since KPMG's (1995) inaugural annual review and have developed their approaches since the early days of visible philanthropy and repainting local schools, the forms of legitimacy created correspond to a pragmatic level rather than more desirable cognitive levels where CSR activity. Cognitive forms would allow evaluators to make sense of the place of accountancy firms in an ever-changing world or present CSR as something so integral to the firms' operations that it would be inconceivable for them to be in business without it. Therefore, future studies of a longitudinal nature would be useful to map firms changing responses to a mutable environment.

Third, although respondents were not asked specifically about ethics, it was mostly absent from their accounts. It is plausible that ethics is such a sine qua non within the accountancy industry that it lives in a separate domain of professional ethics and transparency reporting some distance away from CSR. It would then be interesting to explore further the relationship between CSR and professional ethics in the accountancy context.

Fourth, an unexplored area in the CSR literature is who are the CSR practitioners themselves? In the regularised world of accountancy firms where partners and employees are professionally-trained and members of professional bodies with regulatory status, where support workers, for example, personnel practitioners have similar levels of qualification, what are the defining attributes and qualifications of the CSR practitioners themselves? Prior work in CSR points to the influence of managers in CSR practice, which was less evident in this study. Therefore, greater consideration of the implementers of CSR would be of interest and their relationship to the firms in which they operate.

\section{Acknowledgement}

The financial support of the Institute of Chartered Accountants of England and Wales' Research Board is gratefully acknowledged along with three anonymous reviewers. Finally, I am indebted to those participants who freely and generously gave their time interviewed. 


\section{REFERENCES}

Adams, C., Hill, W.Y., \& Roberts, C.B. (1998). Corporate social reporting practices in Western Europe: Legitimating corporate behaviour? British Accounting Review, 30, $1-21$.

Aguilera, R.V., Rupp, D.E., Williams, C.A., Ganapathi, J. (2007). Putting the S back in corporate social responsibility: A multilevel theory of social change in organizations. Academy of Management Review, 32 (4), 836-863.

Archel, P., Husillos, J., Larrinaga, C. and Spence, C. (2009). Social disclosure, legitimacy theory and the role of the state. Accounting, Auditing \& Accountability Journal, 22(8),1284-1307.

Backhaus, K.B., Stone, B.A., Heiner, K. (2002). Exploring the relationship between corporate social performance and employer attractiveness, Business and Society, 4 (3), 292-318.

Basu, K., Palazzo, G. (2008). Corporate Social Responsibility: A process model of sensemaking. Academy of Management Review, 33 (2), 122-136

Belal, A., Owen D.L. (2015).The rise and fall of stand-alone social reporting in a multinational subsidiary in Bangladesh: a case study. Accounting, Auditing \& Accountability Journal, 28 (7), 1160-1192.

Bhattacharya, C. B., Sen, S. (2004). Doing better at doing good: When, why, and how consumers respond to corporate social initiatives. California Management Review, 47 (1), 9-24.

Branco, M.C., Rodrigues, L.L. (2008). Factors influencing social responsibility disclosure by Portuguese companies. Journal of Business Ethics, 83 (4), 685-701.

Braun, V., Clarke, V. (2013). Successful Qualitative Research. London: Sage.

Brown, N., Deegan, C. (1998). The public disclosure of environmental performance information-a dual test of media agenda setting theory and legitimacy theory, Accounting and Business Research 29 (1), 21-41.

Brown, A.D., Toyoki, S. (2013). Identity work and legitimacy, Organization Studies, 34 (7), 875-896.

Carroll, A.B., Shabana, K.M. (2010). The business case for corporate social responsibility: a review of concepts, research and practice. International Journal of Management Reviews12 (1), 85-105.

Castello, I., Lozano, J.M. (2009). From risk management to citizenship corporate social responsibility: analysis of strategic drivers of change. Corporate Governance, 9 (4), 373-385.

Castello, I., Lozano, J.M. (2011). Searching for new forms of legitimacy through corporate responsibility rhetoric, Journal of Business Ethics, 100, 11-29.

Dahlsrud, A. (2008). How corporate social responsibility is defined: an analysis of 37 definitions. Corporate social responsibility and environmental management, 15 (1), 1-13.

den Hond, F., de Bakker, F. (2007). Ideologically motivated activism: How activist groups influence corporate social change activities. Academy of Management Review, 32 (6), 901-324.

Deephouse, D., Bundy, J., Tost, L.P., Suchman, M.C. (2017). Organizational legitimacy: Six key questions. In The SAGE Handbook of Organizational Institutionalism. (2nd Ed.) (Eds.: R. Greenwood, C. Oliver, T. Lawrence, R. Meyer). Thousand Oaks, CA: Sage.

Duff, A. (2011). Big four accounting firms' annual reviews: A photo analysis of gender and race portrayals. Critical Perspectives on Accounting, 22 (1), 20-38.

Duff, A. (2016). Corporate social responsibility reporting in professional accounting firms. British Accounting Review, 48 (1), 74-86. 
Duff, A. (2017). Social mobility and Fair Access to the accountancy profession in the United Kingdom: Evidence from Big Four and mid-tier firms, Accounting, Auditing and Accountability Journal, 30 (5), 1082-1110.

Erkama, N., Vaara, E. (2010). Struggles over legitimacy in global organizational restructuring: A rhetorical perspective on legitimation strategies and dynamics in a shutdown case. Organization Studies, 31(7), 813-839.

European Commission (EC) (2011). Proposal for a regulation on the quality of audits of public-interest entities and proposal for a directive to enhance the single market for statutory audits (November 2011); Brussels: EC.

Financial Reporting Council, (2016). Key facts and trends in the accountancy profession. Financial Reporting Council, London.

Gambling, T. (1977). Magic, accounting and morale. Accounting, Organizations and Society, 2 (2), 141-151.

Georgiou, O. and Jack, L., 2011. In pursuit of legitimacy: A history behind fair value accounting. The British Accounting Review, 43 (4), 311-323.

Greening, D., Turban, D., Daniel, B. (2000). Corporate social responsibility as a competitive advantage in attracting a quality workforce, Business and Society, 39 (3), 254-281.

Hemingway, C. A., Maclagan, P. W. (2004). Managers' personal values as drivers of corporate social responsibility. Journal of Business Ethics, 50 (1), 33-44.

High Fliers (2016). The graduate market in 2016. London: High Fliers.

Hodges, S., Young, L. (2009). Unconsciously competent: Academia's neglect of marketing success in the professions. Journal of Relationship Marketing, 8 (1), 36-49.

House of Lords (2011). Economic Affairs Committee- Second Report Auditors: Market concentration and their role, Volume I (HL Paper 119-I). www. parliament.gov.uk

Huselid, M.A. (1995). The impact of human resource management practises on turnover, productivity, and corporate financial performance. Academy of Management Journal, 38 (3), 673-703.

Jamali, D., Mirshak, R. (2007). Corporate social responsibility (CSR): theory and practice in a developing country context. Journal of Business Ethics, 72 (3), 243-262.

Kornberger, M., Justesen, L., Mouritsen, J. (2011). “When you make manager, we put a big mountain in front of you": An ethnography of managers in a Big 4 accounting firm, Accounting, Organizations and Society, 36 (8), 514-533.

Kurucz, E., Colbert, B., Wheeler, D. (2008). The business case for corporate social responsibility. In: A. Crane, A. McWilliams, D. Matten, J. Moon, and D. Siegel, eds. The Oxford Handbook of Corporate Social Responsibility; Oxford: Oxford University Press, 83-112;

Laux, C., Leuz, C. (2009). The crisis of fair-value accounting: Making sense of the recent debate. Accounting, Organizations and Society, 34 (6), 826-834.

Lim, A., Tsutsui, K. (2012). Globalization and commitment in corporate social responsibility cross-national analyses of institutional and political-economy effects. American Sociological Review, 77 (1), 69-98.

Magness, V. (2006). Strategic posture, financial performance and environmental disclosure: an empirical test of legitimacy theory. Accounting, Auditing \& Accountability Journal, 19(4), 540-563.

Malsch, B. (2013). Politicizing the expertise of the accounting industry in the realm of corporate social responsibility. Accounting Organisations and Society, 38 (2), 149-168.

Malsch, B., Gendron, Y. (2013). Re-theorizing change: Institutional experimentation and the struggle for domination in the field of public accounting. Journal of Management Studies, 50(5): 870-899. 
Margolis, J.D., Walsh, S. (2003). Misery loves companies: Rethinking social initiatives by business. Administrative Science Quarterly, 48 (2), 268-305;

Matten, D., Moon, J. (2007). Implicit and explicit CSR: A conceptual framework for a comparison understanding of corporate social responsibility. Academy of Management Review, 32 (4), 404-424.

McWilliams, A., Siegel, D. (2001). Corporate social responsibility: A theory of the firm perspective. Academy of Management Review, 26 (1), 117-127.

Milne, M., Patten, D. (2002), Securing organizational legitimacy: an experimental decision case examining the impact of environmental disclosures, Accounting, Auditing \& Accountability Journal, 15 (3), 372-405.

Mobus, J.L. (2005). Mandatory environmental disclosures in a legitimacy theory context. Accounting, Auditing \& Accountability Journal, 18(4), 492-517.

Momin, M.A. Parker, L.D. (2013). Motivations for corporate social responsibility reporting by MNC subsidiaries in an emerging country: The case of Bangladesh. British Accounting Review, 45 (3), 215-228.

Moon, J., Vogel, D. (2008). Corporate social responsibility, government, and civil society. In: A. Crane, A. McWilliams, D. Matten, J. Moon, and D. Siegel, eds. The Oxford Handbook of Corporate Social Responsibility (p p.3-18). Oxford: Oxford University Press.

O'Dwyer, B. (2003). The ponderous evolution of corporate environmental reporting in Ireland. Recent evidence from publicly listed companies. Corporate Social Responsibility and Environmental Management, 10(2), 91-100.

O’Dwyer, B., Owen, D., Unerman, J. (2011). Seeking legitimacy for new assurance forms: The case of assurance on sustainability reporting, Accounting Organizations and Society, 36 (1), 31-52.

Orlitzky, M., 2008. Corporate social performance and financial performance: a research synthesis. In: A. Crane, A. McWilliams, D. Matten, J. Moon, and D. Siegel, eds. The Oxford Handbook of Corporate Social Responsibility(pp. 3-18). Oxford: Oxford University Press.

Orlitzky, M., Schmidt, F.L., Rynes, S.L. (2003). Corporate social and financial performance: A meta-analysis. Organization Studies, 24 (4), 403-441.

Oshionebo, E. (2009). Regulating Transnational Corporations in Domestic and International Regimes: An African Case Study. Toronto: University of Toronto Press.

Pfeffer, J. (1994). Competitive Advantage Through People, California Management Review, 36 (2), 9-28.

Poland, B.D. (2002). Transcription quality. In J.F. Gubrieum and J.A. Holstein (Eds.), Handbook of Interview Research: Context and Method (pp.629-650). Thousand Oaks, CA: Sage.

Power, M. (1997). Expertise and the construction of relevance: Accountants and the environmental audit, Accounting Organisations and Society, 22(2), 123-146.

PriceWaterhouseCoopers (PwC) (2011). Annual Review. London: PwC.

Pruzan, P. (2008). Spirituality as a firm basis for corporate social responsibility, In A. Crane, A. McWilliams, D. Matten, J. Moon, and D. Siegel (Eds.) The Oxford Handbook of Corporate Social Responsibility (552-559), Oxford: Oxford University Press.

Rodrigo, P., Arenas, D. (2008). Do employees care about CSR programs? A typology of employees according to their attitudes. Journal of Business Ethics, 83 (2), 265 283.

Rupp, D. E., Ganapathi, J., Aguilera, R. V., Williams, C. A. (2006). Employee reactions to corporate social responsibility: An organizational justice framework. Journal of Organizational Behavior, 27 (4), 537-543. 
Sagafi-Nejad, T., Dunning, J.H. (2008). The UN and transnational corporations: from code of conduct to global compact. Bloomington, IN: Indiana University Press.

Saldaňa, J. (2009). The coding manual for qualitative researchers. Thousand Oaks, CA: Sage.

Schwartz, P., Gibb, B. (1999). When good companies do bad things: Responsibility and risk in an age of globalization. New York: Wiley.

Scott, W. R. (1995). Introduction: institutional theory and organizations. In W.R. Scott, S.M. Christensen (Eds.) The institutional construction of organizations (pp. 11-23), Thousand Oaks, CA: Sage.

Sen, S. and Bhattacharya, C.B. (2001). Does doing good always lead to doing better? Consumer reactions to corporate social responsibility. Journal of Marketing Research, 38 (2), 225-243.

Shamir, R. (2004). The de-radicalization of corporate social responsibility, Critical Sociology, 30 (4), 669-689.

Sikka, P. (2009). Financial Crisis and the Silence of the Auditors', Accounting, Organizations and Society, 34 (6-7), 868-73.

Sikka, P. (2010). Smoke and mirrors: Corporate social responsibility and tax avoidance. Accounting Forum, 34 (3), 153-168.

Sikka, P. Hampton, M. (2005). The role of accountancy firms in tax avoidance: Some evidence and issues, Accounting Forum, 29 (3), 325-343

Smith, N.C. (2008). Consumers as drivers of corporate social responsibility. In A. Crane, A. McWilliams, D. Matten, J. Moon, and D. Siegel (Eds.) The Oxford Handbook of Corporate Social Responsibility (pp.281-302), Oxford: Oxford University Press.

Steger. U. (2008). Future perspectives of corporate social responsibility: Where are we coming from? Where are we heading? In A. Crane, A. McWilliams, D. Matten, J. Moon, and D. Siegel, (Eds.) The Oxford Handbook of Corporate Social Responsibility, (pp.560-567), Oxford: Oxford University Press.

Steurer, R. (2010). The role of governments in corporate social responsibility: characterizing public policies on CSR in Europe. Policy Sciences, 43(1), 49-72.

Stone, G. (2012). The effectiveness of newsletters in accountants' client relations with small business managers: An Australian qualitative study, Qualitative Research in Accounting \& Management, 9 (1), 21 - 43.

Suchman, M.C. (1995). Managing legitimacy: Strategic and institutional approaches. Academy of Management Review, 20 (3), 571-610.

Terry, N. (2016). Doing thematic analysis. In: E. Lyons \& A. Coyle (Eds.), Analysing Qualitative Data in Psychology, (pp.104-118), London: Sage.

Turban, D.B., \& Greening, D.W. (1996). Corporate social performance and organizational attractiveness to prospective employees, Academy of Management Journal, 40 (3), 658-672.

Vallentin, S. (2015). Governmentalities of CSR: Danish Government Policy as a Reflection of Political Difference, Journal of Business Ethics, 127 (1), 33-47.

Van Marrewijk, M. (2003). Concepts and definitions of CSR and corporate sustainability: between agency and communion. Journal of Business Ethics, 44 (2-3), 95-105.

van Staden, C.J. and Hooks, J. (2007). A comprehensive comparison of corporate environmental reporting and responsiveness. The British Accounting Review, $39(3), 197-210$.

Vogel, D. (2005). The market for virtue: The potential limits of corporate social responsibility. Washington, DC: Brookings Institution Press;

Waldman, D., Siegel, D.S., Javidan, M. (2006). Components of CEO transformational leadership and corporate social responsibility, Journal of Management Studies, 43 (8), 1703-25.

Williams, C.A., Aguilera, R.V. (2008). Corporate social responsibility in a comparative 
perspective. In A. Crane, A. McWilliams, D. Matten, J. Moon, and D. Siegel, (Eds.) The Oxford Handbook of Corporate Social Responsibility (pp. 452-472). Oxford: Oxford University Press.

Zilber, T.B. (2009). Institutional maintenance as narrative acts. In T.B. Lawrence, R. Suddaby, B. Leca (Eds.) Institutional work: Actors and agency in institutional studies of organizations (pp. 205-235). Cambridge University Press, Cambridge. 


\section{TABLES}

\begin{tabular}{|c|c|c|c|}
\hline & Pragmatic & Moral & Cognitive \\
\hline Definition & $\begin{array}{l}\text { Self-interested calculations of } \\
\text { organisation's immediate audiences }\end{array}$ & $\begin{array}{l}\text { A positive normative evaluation of the } \\
\text { organisation }\end{array}$ & $\begin{array}{l}\text { Cognisance of the organisation as necessary or } \\
\text { inevitable }\end{array}$ \\
\hline $\begin{array}{l}\text { Forms of legitimacy } \\
\text { maintained } \\
\text { (definition) }\end{array}$ & $\begin{array}{l}\text { Exchange } \\
\text { Support for a policy expected to yield } \\
\text { value to an audience } \\
\text { Influence } \\
\quad \text { Organisation is of benefit to audience's } \\
\text { wider interests } \\
\text { Dispositional } \\
\text { Personification of organisations with } \\
\text { tastes, interests, styles etc. }\end{array}$ & $\begin{array}{l}\text { Consequential } \\
\text { Evaluation of outputs } \\
\text { Procedural } \\
\quad \text { Evaluations of techniques and procedures } \\
\text { Structural } \\
\quad \text { Evaluation of categories and structures } \\
\text { Personal } \\
\quad \text { Charisma of individual leaders }\end{array}$ & $\begin{array}{l}\text { Comprehensibility } \\
\text { Availability of cultural models that explain need } \\
\text { for organisation } \\
\text { Taken-for-grantedness } \\
\quad \text { A state where alternatives unthinkable and } \\
\text { challenges impossible }\end{array}$ \\
\hline Power & Weak & Moderate & Strong \\
\hline $\begin{array}{l}\text { Longevity } \\
\text { Strategies }\end{array}$ & Temporary & Moderate & Long-lasting \\
\hline 1. Perceive change & \multicolumn{3}{|c|}{$\begin{array}{c}\text { Monitor the cultural environment, assimilating elements of the environment into decision-making and employ personnel to act as bridges across } \\
\text { environments }\end{array}$} \\
\hline \multirow{3}{*}{$\begin{array}{l}\text { 2. Protect } \\
\text { accomplishments }\end{array}$} & $\begin{array}{l}\text { Co-opt multiple audiences into decision- } \\
\text { making }\end{array}$ & $\begin{array}{l}\text { To understand emerging moral beliefs, } \\
\text { organisation must incorporate multiple ethics }\end{array}$ & $\begin{array}{l}\text { Explore multiple outlooks to understand others' } \\
\text { taken-for-granted assumptions }\end{array}$ \\
\hline & \multicolumn{3}{|c|}{ Convert legitimacy from episodic to more continual forms } \\
\hline & Accrue pragmatic attributes e.g. trust & Accrue moral attributes e.g. esteem & $\begin{array}{l}\text { Construct social links between the organisation } \\
\text { and its environment (cognitive) }\end{array}$ \\
\hline
\end{tabular}

Table 1: Levels and forms of legitimacy and legitimacy strategies 


\begin{tabular}{lrr}
\hline Firm size category & $\begin{array}{c}\text { Average Fee Levels } \\
\text { E millions }\end{array}$ & $\begin{array}{c}\text { Average Fees per Partner } \\
\text { Emillions }\end{array}$ \\
\hline Big Four & 1,684 & 2.7 \\
Firms ranked 5 to 11 & 217 & 1.2 \\
Firms ranked 12 to 20 & 60 & 0.8 \\
\hline
\end{tabular}

Table 2: Market structure of UK accountancy industry in 2010 by fee levels

\begin{tabular}{llll}
\hline Interviewee & Firm & Firm Type & Job Role \\
\hline 1 & 1 & Big Four & Director, CSR \\
2 & 1 & Big Four & Advisor, Diversity \\
3 & 1 & Big Four & Partner \\
4 & 2 & Big Four & Partner \\
5 & 2 & Big Four & Manager, CSR \\
6 & 3 & Big Four & Director (Communities) \\
7 & 4 & Big Four & Director CSR \\
8 & 5 & Upper middle tier & CSR Manager \\
9 & 6 & Upper middle tier & Director (Risk) \\
10 & 7 & Upper middle tier & Director (HR) \\
11 & 8 & Upper middle tier & Director (Operations) \\
12 & 9 & Upper middle tier & Partner \\
13 & 9 & Upper middle tier & Partner \\
14 & 9 & Upper middle tier & Director (administration) \\
15 & 10 & Upper middle tier & Director (HR) \\
16 & 11 & Upper middle tier & Director \\
17 & 12 & Lower middle tier & Chairman \\
18 & 13 & Lower middle tier & Senior Partner \\
19 & 14 & Lower middle tier & Senior Manager \\
20 & 15 & Lower middle tier & Managing Partner \\
21 & 16 & Lower middle tier & Chairman \\
22 & 17 & Lower middle tier & Managing Partner \\
23 & 18 & Lower middle tier & Partner \\
\hline
\end{tabular}

Table 3: Participants, firms and job roles 


\begin{tabular}{|c|c|c|c|c|}
\hline & & Audience & & \\
\hline & Clients & Graduates & Other external & Internal \\
\hline \multirow{2}{*}{$\begin{array}{l}\text { Types of } \\
\text { legitimacy } \\
\text { maintained }\end{array}$} & $\begin{array}{l}\text { Pragmatic: } \\
\text { - exchange }\end{array}$ & $\begin{array}{l}\text { Pragmatic: } \\
\quad \text { - influence }\end{array}$ & $\begin{array}{l}\text { Moral } \\
\text { - consequential }\end{array}$ & $\begin{array}{l}\text { Pragmatic: } \\
\text { - exchange }\end{array}$ \\
\hline & - influence & - dispositional & - procedural & - influence \\
\hline \multicolumn{5}{|l|}{ Strategies } \\
\hline \multirow[t]{2}{*}{ Perceive change } & Identify client's desire for CSR strategy & $\begin{array}{l}\text { Pitch employment at graduate groups } \\
\text { who support the firm }\end{array}$ & $\begin{array}{l}\text { Identify greater calls for } \\
\text { accountability }\end{array}$ & Generation X versus Generation $Y$ \\
\hline & $\begin{array}{l}\text { Differentiate between different client } \\
\text { groups }\end{array}$ & $\begin{array}{l}\text { Recognise graduates are not a } \\
\text { homogenous grouping }\end{array}$ & - & $\begin{array}{l}\text { Differentiate between 'our people' } \\
\text { who care versus the apathetic }\end{array}$ \\
\hline \multirow[t]{2}{*}{$\begin{array}{l}\text { Protect } \\
\text { accomplishments }\end{array}$} & $\begin{array}{l}\text { Convert from episodic to continual forms } \\
\text { of CSR }\end{array}$ & $\begin{array}{l}\text { Report using graduate recruitment } \\
\text { literature }\end{array}$ & $\begin{array}{l}\text { Report actions and emphasize } \\
\text { the continual }\end{array}$ & Emphasize commitment via actions \\
\hline & $\begin{array}{l}\text { Distinguish between regulatory } \\
\text { legitimacy and public support }\end{array}$ & $\begin{array}{l}\text { Distinguish between the availability of } \\
\text { employment and graduate attitudes }\end{array}$ & $\begin{array}{l}\text { Differentiate between } \\
\text { regulatory legitimacy and } \\
\text { public support }\end{array}$ & $\begin{array}{l}\text { Differentiate between simple } \\
\text { exchange relationships to affective } \\
\text { commitment }\end{array}$ \\
\hline \multicolumn{5}{|l|}{ Examples } \\
\hline \multirow[t]{2}{*}{ Perceive change } & $\begin{array}{l}\text { Recognition of greater need for } \\
\text { transparent CSR policy and monitored } \\
\text { actions by some client audiences }\end{array}$ & $\begin{array}{l}\text { Create and support volunteering as a } \\
\text { firm-wide 'good'; explain role of CSR in } \\
\text { work-life balance }\end{array}$ & $\begin{array}{l}\text { Maintain relations with local } \\
\text { communities, trade } \\
\text { associations to build business } \\
\text { linkages }\end{array}$ & $\begin{array}{l}\text { Recognition of importance of CSR to } \\
\text { generation Y (junior people) to } \\
\text { longstanding generation X } \\
\text { 'Thatcher's Children' }\end{array}$ \\
\hline & $\begin{array}{l}\text { Cleavage between sectors in favour of } \\
\text { CSR (charities, government, NGOs, } \\
\text { multinationals) and non-believers (SMEs, } \\
\text { managed business) }\end{array}$ & $\begin{array}{l}\text { Sell CSR activity alongside other forms } \\
\text { of recruitment marketing activity (e.g. } \\
\text { training, work-life balance, career } \\
\text { progression) }\end{array}$ & - & $\begin{array}{l}\text { Emphasize longstanding benefits of } \\
\text { CSR to 'our people' }\end{array}$ \\
\hline \multirow[t]{2}{*}{$\begin{array}{l}\text { Protect } \\
\text { accomplishments }\end{array}$} & $\begin{array}{l}\text { Policy exemplifies continuous } \\
\text { commitment to CSR in various forms with } \\
\text { reported examples }\end{array}$ & $\begin{array}{l}\text { Publicise winning awards and } \\
\text { celebration events }\end{array}$ & $\begin{array}{l}\text { Active involvement with CSR } \\
\text { regulatory agents }\end{array}$ & $\begin{array}{l}\text { Institutionalise and make CSR } \\
\text { mainstream using policy, regular } \\
\text { events }\end{array}$ \\
\hline & $\begin{array}{l}\text { Strengthen client relationships and win } \\
\text { work by leveraging good CSR reputation }\end{array}$ & $\begin{array}{l}\text { Recognition of importance of recruiting } \\
\text { the best talent and 'offer a place where } \\
\text { they can thrive' }\end{array}$ & $\begin{array}{l}\text { Longstanding commitments to } \\
\text { particular charities, ventures, } \\
\text { communities }\end{array}$ & $\begin{array}{l}\text { Employment relationship moves } \\
\text { beyond transactional to greater } \\
\text { mutual commitment }\end{array}$ \\
\hline
\end{tabular}

Table 4: Summary of interviews - LMSs employed with clients, graduates, other external and internal audiences 


\begin{tabular}{|c|c|c|c|}
\hline Audience & Assumptions & Motivations & Metaphors \\
\hline Clients & $\begin{array}{l}\text { Some client groups require suppliers } \\
\text { (accountancy firms) to maintain a CSR } \\
\text { presence. } \\
\text { Suppliers are evaluated, to varying degrees, by } \\
\text { their CSR policy in tender documents }\end{array}$ & $\begin{array}{l}\text { - Support for the firm's reputation despite } \\
\text { criticism from powerful commentators } \\
\text { - CSR policies help win work with CSR- } \\
\text { sensitive sectors }\end{array}$ & 'CSR is good for business' \\
\hline $\begin{array}{l}\text { Graduates } \\
\text { (potential } \\
\text { employees) }\end{array}$ & $\begin{array}{l}\text { - } \quad \text { Younger staff are believed to value CSR } \\
\text { - CSR is a legitimacy signal }\end{array}$ & $\begin{array}{l}\text { Talent management strategy to ensure } \\
\text { competitiveness of recruitment within the } \\
\text { industry and relative to other sectors } \\
\text { - Integration of CSR discourse into } \\
\text { recruitment and other materials } \\
\text { - Provide tangible examples of volunteering } \\
\text { and associated actions }\end{array}$ & $\begin{array}{l}\text { 'We provide an environment where people can } \\
\text { thrive' }\end{array}$ \\
\hline $\begin{array}{l}\text { Internal } \\
\text { (staff and } \\
\text { partners) }\end{array}$ & $\begin{array}{l}\text { Engaging with under-privileged people } \\
\text { (philanthropy) signals that the firm can be } \\
\text { trusted to act in society's best interests }\end{array}$ & $\begin{array}{l}\text { Retain valuable staff and provide } \\
\text { opportunities, beyond usual day-to-day } \\
\text { accountancy employment, to retain the } \\
\text { interest in working in the firm } \\
\text { - Conflation of CSR with other human } \\
\text { resource initiatives to motivate and retain } \\
\text { staff }\end{array}$ & 'Engaging our people' \\
\hline $\begin{array}{l}\text { External } \\
\text { (communities) }\end{array}$ & $\begin{array}{l}\text { (a minority of) staff enjoy the team aspects } \\
\text { of volunteering and team philanthropy. } \\
\text { Belief this creates a more cohesive team }\end{array}$ & $\begin{array}{l}\text { - Create 'feel good' factors such as } \\
\text { engagement with non-client, non- } \\
\text { regulatory world } \\
\text { - Manufacture moral legitimacy that assists } \\
\text { with the production of pragmatic } \\
\text { legitimacy with clients, graduates and staff. }\end{array}$ & 'Putting something back' \\
\hline
\end{tabular}

Table 5: Summary of findings 
